\title{
JUSTIFICATION OF THE POSSIBLE DIRECTIONS OF PATHOGENETIC THERAPY OF A NEW CORONAVIRUS INFECTION
}

Lobzin YuV', Ivanov $\mathrm{MB}^{2}$, Shustov $\mathrm{EB}^{2}$, Rejnyuk $\mathrm{VL}^{2}$, Fomichev $\mathrm{AV}^{2}$, Sosyukin $\mathrm{AE}^{2}$, Litvincev $\mathrm{BS}^{2} \otimes$

${ }^{1}$ Pediatric Research and Clinical Center for Infectious Disease, Saint Petersburg, 197022, Russian Federation

2 "Institute of Toxicology" of Federal Medico-Biological Agency, Saint Petersburg, 192019, Russian Federation

The article analyses different stages of COVID-19 pathogenesis that drive development of severe complications, including acute respiratory distress syndrome, multiple organ failure and endotoxicosis. COVID-19 progression is described, from the first moments of infection to the disruption of the alveolar-capillary barrier and acute respiratory distress syndrome. The article looks at the causes initiating pathological processes that lead to acute respiratory distress syndrome. The special focus is on oxidative stress, hyperreactivity of the immune system, endothelial dysfunction, and cytotoxic effects of the virus. The article discusses tentative treatments for COVID-19 at different stages of its pathogenesis.

Keywords: coronavirus, medication therapy, endothelial dysfunction, SARS-CoV-2, COVID-19, acute respiratory distress syndrome, oxidative stress, SARS-COV-2

$\triangle$ Correspondence should be addressed: Bogdan S. Litvincev, MD, Ph.D, DSci., leading researcher of the scientific information and analytical department "Institute of toxicology" of Federal Medico-Biological Agency, Saint Petersburg, 192019, Russian Federation. E-mail: litvintsevs@yandex.ru

Received: 26.06.2020 Accepted: 09.07.2020 Published online: 15.07.2020

DOI: $10.47183 /$ mes.2020.002

\section{ОБОСНОВАНИЕ ВОЗМОЖНЫХ НАПРАВЛЕНИЙ ПАТОГЕНЕТИЧЕСКОЙ ТЕРАПИИ НОВОЙ КОРОНАВИРУСНОЙ ИНФЕКЦИИ}

\author{
Ю. В. Лобзин ${ }^{1}$, М. Б. Иванов², Е. Б. Шустов ${ }^{2}$ В. Л. Рейнюк², А. В. Фомичев², А. Е. Сосюкин², Б. С. Литвинцев
}

1 Федеральное государственное бюджетное учреждение «Детский научно-клинический центр инфекционных болезней Федерального медико-биологического агентства", 197022, Санкт-Петербург

2 Федеральное государственное бюджетное учреждение науки «Институт токсикологии Федерального медико-биологического агентства», 192019, Санкт-Петербург

В статье анализируются звенья патогенеза новой коронавирусной инфекции, приводящие к тяжелым клиническим проявлениям заболевания - острому респираторному дистресс-синдрому, полиорганной недостаточности и эндотоксикозу. Представлена последовательность развития инсекционного процесса с момента попадания вируса в организм из внешней среды до повреждения альвеолярно-капиллярного барьера и развития острого респираторного дистресс-синдрома. Описаны факторы инициации патологических процессов, приводящих к развитию острого респираторного дистресс-синдрома, среди которых особое внимание уделено оксидативному стрессу, гиперреактивности иммунной системы, эндотелиальной дисфункции и цитотоксическому действию вируса. Обсуждаются возможные фармакотерапевтические направления лечения COVID-19 с учетом разных звеньев патогенеза.

Ключевые слова: коронавирус, фармакотерапия, эндотелиальная дисфункция, SARS-CoV-2, COVID-19, острый респираторный дистресс-синдром, оксидативный стресс, SARS-COV-2

$\bowtie$ Для корреспонденции: Литвинцев Богдан Сергеевич (Litvincev Bogdan Sergeevich), доктор медицинских наук, ведущий научный сотрудник научного информационно-аналитического отдела ФГБУН «Институт токсикологии Федерального медико-биологического агентства», 192019, г. Санкт-Петербург, e-mail: litvintsevs@yandex.ru

Статья получена: 19.06.2020 Статья принята к печати: 17.07.2020 Опубликована онлайн: 26.07.2020

DOI: $10.47183 /$ mes.2020.002

At the end of December 2019, the first cases of atypical pneumonia that was clinically different from all previously known viral pneumonias were reported in Wuhan, China. The rapid spread of the novel RNA SARS-CoV-2 (Severe Acute Respiratory Syndrome-related Coronavirus 2) to other countries in March 2020 pressured the World Health Organization to declare a pandemic [1]. According to the data collected by the WHO's monitoring center, the incidence of the novel coronavirus infection (COVID-19) is obstinately high. Diagnostic and therapeutic approaches used in patients with COVID-19 are largely standardized and work well in most cases; however, the unrelenting death rates observed in patients with severe infection raise some questions about their efficacy [2]. So far no consensus has been reached in the scientific community about the pathogenesis of COVID-19, and the mechanisms underlying progression to irreversible complications are not fully clear [3]. To contain the spread of the disease and minimize its consequences, systematic updates are needed on the international literature about the clinical course variations of COVID-19 and the efficacy of proposed treatments, including medication therapy at different stages of its pathogenesis.
According to the experts of the Russian Ministry of Healthcare, the main approach to the management of patients with COVID-19 should be preventive therapy aimed at avoiding disease progression to overt life-threatening symptoms, such as pneumonia, acute respiratory distress syndrome (ARDS) and sepsis.

The aim of this study was to determine promising approaches to COVID-19 treatment at different stages of the disease based on the analysis and systematization of the accumulated data about the pathogenesis of the novel coronavirus infection.

\section{Main part}

The primary routes of human-to-human SARS-CoV-2 transmission are via respiratory droplets or dust particles and indirect physical contact mediated by hands or fomites followed by the virus landing on mucous membranes. The fecal-oral route is also possible when the virus enters the gastrointestinal tract with food or following hand contact with contaminated surfaces; there, SARS-CoV-2 adheres to the mucous membrane of the esophagus, stomach or upper small intestine 
[4]. Besides, transplacental transmission cannot be excluded [5]; however, there have been no reports of intrauterine SARSCoV-2 infection in Russia; a few reported cases of neonatal COVID-19 were attributed to the postnatal exposure to the virus [6].

Exogenous factors play a significant role in promoting infection, including chronic intoxication with psychoactive drugs that substantially increases the risk of SARS-CoV-2 infection and worsens its course [7]. For example, smoking spurs progression of the novel coronavirus infection and increases the risk of its aggravated course [8]; alcohol abuse can compromise the immunity and increase both the risk of infection and its complications [9]. Apart from exogenous factors, severity of COVID-19 is determined by pre-existing conditions, including cancer, hypertension, diabetes mellitus, chronic obstructive pulmonary disease and other disorders that under certain conditions cause irreversible systemic damage [10].

Standard antiviral prophylaxis is very effective in preventing the spread of the infection. Social distancing (1.5-2m) and good personal/respiratory hygiene are simple yet effective measures recognized worldwide. However, their effect should be reinforced with viricidal disinfectants [11].

The infection starts to unfold once SARS-CoV-2 comes in contact with the sialic acid-producing mucosal epithelium of the conjunctiva, the nasal/oral cavity, the respiratory tract, and the upper gastrointestinal tract [12]. Sialic acids constituting transmembrane glycoproteins are targets for the viral hemagglutinin-esterase, which is a surface protein of the viral envelope that facilitates viral entry into the cell and is required for virus replication. When the infected mucosal cells release a massive amount of new virions and proinflammatory factors, the virus can enter the bloodstream and travel to tissues containing its cellular targets; this leads to the development of clinical symptoms following the incubation period [13].

Transmembrane glycoproteins are the cellular gateway for SARS-CoV. Angiotensin-converting enzyme 2 (ACE2) has been identified as the main receptor for the novel coronavirus, as well as for the older SARS-CoV strain [5, 14, 15]. Its primary function is to regulate the activity of angiotensin II, which increases smooth muscle tone and affects heart and kidney function. ACE2 cleaves off one amino acid from angiotensin II, thereby altering its properties: the resultant molecule interacts more actively with angiotensin II membrane receptors, causing pronounced short-term local vasoconstriction. Besides, ACE2 modulates amino acid transport across the cell membrane by acting as a chaperone for one of amino acid transporters. The interaction between the membrane domain of ACE2 and the amino acid transporter on the internal side of the cell membrane facilitates viral invasion. ACE2 is predominantly expressed on the surface of type II alveolar cells, making them susceptible targets for SARS-CoV-2 [16]. Other ACE2-expressing cells (type I alveolar cells, macrophages, pulmonary/cerebral/ cardiac/renal vascular endothelial cell, epithelial cells of the bronchi and bronchioles, esophagus, duodenum, ileum, and bladder, pancreatic cells, cortical and brain stem neurons) total to $20 \%$ of potential targets that the novel coronavirus can infect using ACE2 as an entry point.

According to some studies, one more glycoprotein from the transmembrane serine protease family is needed to mediate viral entry into the cell through ACE2 [17]. This protease is found in the vicinity of calcium channels, close to ACE2, and is activated through contact with a receptor-binding domain of the virus, cathepsin or under lowered $\mathrm{pH}$; the protease fosters fusion of the virus envelope with the cell membrane [18]. Another mediator of the fusion process is furin, the protease that cleaves proteins at paired basic amino acids sites and participates in viral protein processing (maturation) [19].

Basigin, the transmembrane glycoprotein found in most cells, is another entry point for SARS-CoV-2. It is also known as cluster of differentiation 147 (CD147) or extracellular matrix metalloproteinase (MMP) inducer $[17,19]$. The spike proteins of the coronavirus (spike-shaped protrusions from its surface) bind to basigin, as is also the case with ACE2. The main functions of basigin are MMP activation, participation in cell-cell interactions and spermiogenesis. Basigin effects are exerted through pronounced activation of blood monocytes, platelets and S-selectin, release of positively charged collagen and formation of parietal thrombi, followed by a reduction in permeability of capillary tissue barriers and macrophages migration from the bloodstream to the site of inflammation. This protein is chiefly found in erythrocytes, lymphocytes, retinal cells, fibroblasts, epithelial, endothelial and prostate cells [20]. Perhaps, this mechanism of viral entry and subsequent virus replication is implicated in coagulation disorders and formation of intravascular thrombi in organs affected by the virus, especially in the setting of endothelial dysfunction.

Another transmembrane glycoprotein that SARS-CoV-2 can bind to is a CD26 surface antigen, also known as DDP4 (dipeptidyl peptidase 4); it is a serine exopeptidase that cleaves proline- and alanine-containing dipeptides from the $\mathrm{N}$-terminus of a protein molecule [21]. The ability of this glycoprotein to participate in coronavirus trafficking into the intracellular compartment was previously confirmed for MERS-CoV, the causative agent of the Middle East Respiratory Syndrome [22].

The mechanism of the novel coronavirus infection is shown in Fig. 1.

In case of any respiratory viral infection, it is essential to boost the local immune defenses as early as possible at the sites of primary contact of the virus with mucous membranes [23]. Therefore, it is advisable to use therapeutic agents that stimulate local and systemic immunity so as to inhibit replication of SARS-CoV-2 in the earliest stages of infection, before the onset of pronounced clinical symptoms. The list of such medications includes interferons exerting antiviral, immunostimulatory and antiproliferative effects, peptide and synthetic immunomodulators enhancing the bactericidal activity of neutrophils, and sodium nucleinate-based immunostimulatants that activate non-specific resistance. In his regard, the Russian Ministry of Health recommends nasal formulations of recombinant interferon $\alpha 2 b$ and interferon $\beta 1 \mathrm{~b}$ in combination with lopinavir+ritonavir. At the site of inflammation, the virus can be inactivated with viricidal drugs used in combination therapy against viral pneumonias in patients without respiratory failure; such drugs might hold some promise for treating COVID-19. Fusion inhibitors and/ or angiotensin II receptor blockers can prevent the virus from entering the target cell: their mechanism of action renders these drugs promising candidates for the combination therapy of viral pneumonias complicated by respiratory distress [24]. Soluble genetically engineered traps for the virus, which are currently in development, are another promising therapeutic option; these drugs are based on ACE2 protein fragments attached to the Fc region of human immunoglobulin IgG1 [25]. Viral replication can be stopped with inhibitors of viral proteases and RNA polymerases. However, the efficacy of medication therapy at the stage of viral replication is determined by a variety of factors, and at this point disease progression is not a rare thing. Considering the absence of validated treatments against the novel coronavirus, off-label drugs with antiviral potential might be worth giving a try [26]; their use must comply with 
standards for ethical practice, $\mathrm{WHO}$ recommendations and current legislation.

Damage or death of a target cell is followed by the activation of alveolar macrophages and neutrophils, triggering chemokine release and migration of inflammatory cells into the interstitium. These events are followed by neutrophil infiltration of the affected site. The alveolar-capillary barrier becomes increasingly permeable, allowing some fluid to build up in alveoli and the pulmonary interstitium. At this stage, radiographic (CT) findings are consistent with specific pneumonia [27]. Further evolution of the disease will probably depend on a number of exogenous and endogenous factors.

Clinical course variations of the novel coronavirus infection progressing to pneumonia have been described in the guidance released by the Russian Ministry of Healthcare [11], FMBA guidelines [28] and other sources [1, 17, 29, 30]. COVID-19 can progress to pneumonia if the virus transmitted through the air invades the alveolar space (in this case, the target is type II alveolar cells) or when the course of the disease resembles that of influenza and the virus enters the bloodstream (in this case, it targets endothelial cells of pulmonary capillaries). Inflammation develops in parallel with oxidative stress, which sets in when the intensity of peroxidation and free radical oxidation induced by inflammation overpowers the capacity of enzymic and substrate mechanisms of anti-free radical and antioxidant defenses to negate detrimental effects on cell membranes; eventually, this leads to cell damage or death [31]. Mitochondrial dysfunction that plays a significant role in the development of neurodegenerative disorders is another contributor to cell damage under oxidative stress [32]. Here, medication therapy should be reinforced with antioxidants. Oxidative stress can be reduced by administering high doses of ascorbic acid, lipid and mitochondrial antioxidants, succinates, sulfhydryl donors, antioxidants with enzymic activity and reactive oxygen species inhibitors.

Pneumonia induced by SARS-CoV-2 is often accompanied by respiratory failure; once the infection becomes systemic, it initiates the acute respiratory distress syndrome (ARDS). ARDS is promoted by a combination of different factors, the leading factor being massive release of cytokines (the cytokine storm) from activated alveolar macrophages, neutrophils, endothelial and alveolar cells at the site of the primary infection of lung tissue; this leads to the rapid escalation of cell-membrane damage induced by free radicals [33, 34]. Generalized damage to target cells is accompanied by swift, pronounced activation of alveolar macrophages and

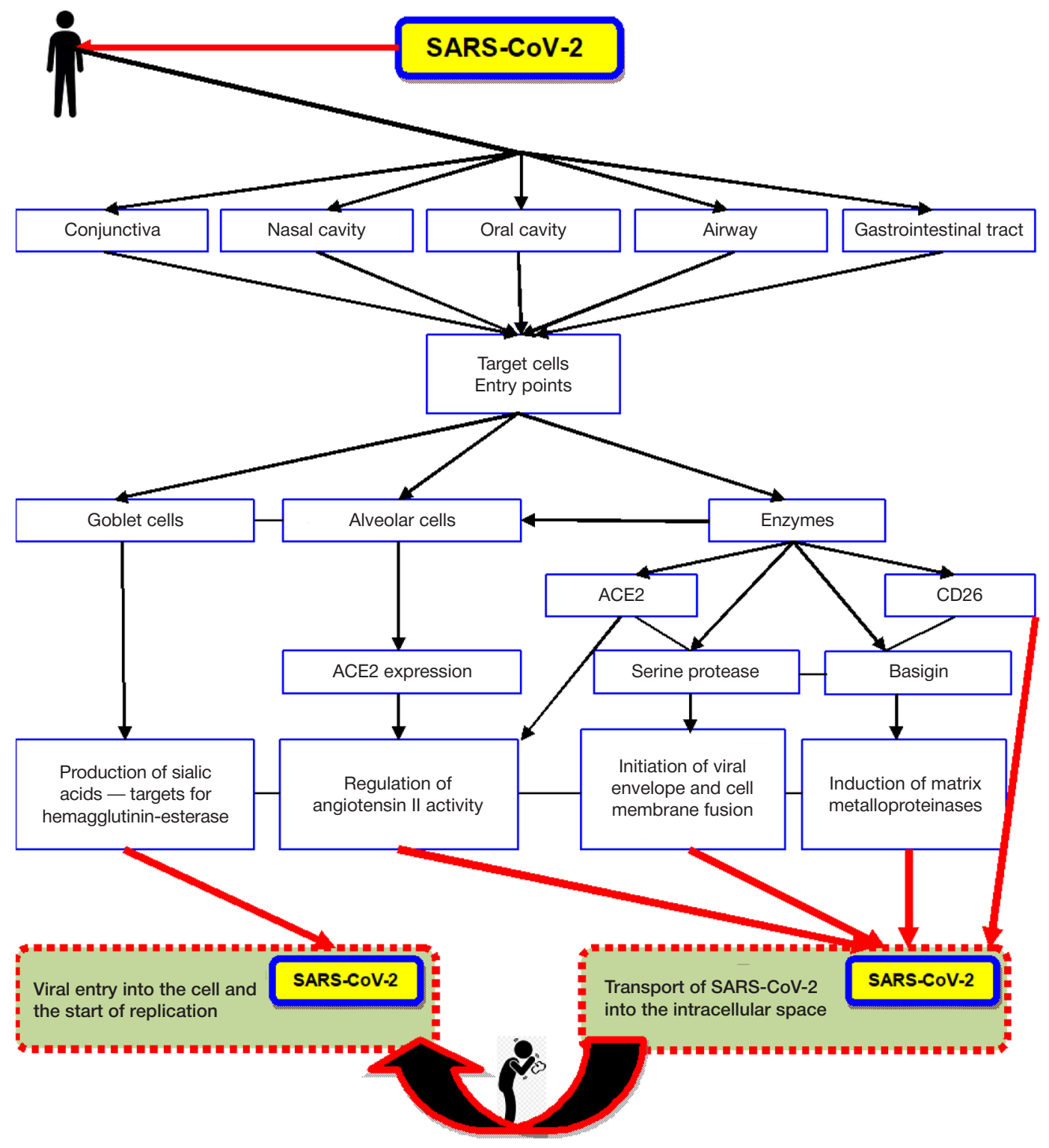

Fig. 1. Initiation of by the novel SARS-CoV virus 
neutrophils, expression of proinflammatory cytokines (IL-1, IL-6. IL-10, tumor necrosis factor), production of prostaglandins and leukotrienes. Activated hyaluronidase and MMP digest the ground substance of the pulmonary interstitium, thereby disrupting the alveolar-capillary barrier. This results in a local microvascular spasm, elevated pulmonary blood pressure and vascular leakage into the interstitial space, causing interstitial edema and hampering gas exchange between alveoli and capillaries. Impaired gas exchange exacerbates hypoxemia; the patient develops respiratory acidosis. Carbon dioxide retention in the blood causes hyperstimulation of brainstem centers controlling respiratory and other autonomic functions of the body. Damaged pulmonary vascular endothelial cells begin to produce more endothelin, triggering the uncontrolled cascade of pathological events and leading to endotoxicosis and multiple organ failure [17].

The schematic representation of complications of the novel coronavirus infection is provided in Fig. 2

Direct damage to type II alveolar cells inflicted by SARSCoV-2 disrupts pulmonary surfactant synthesis and destroys its monolayer as the surfactant is washed off from the alveolar surface by excess tissue fluid coming from the fluid-enriched interstitium [35], triggering alveolar collapse and loss of lung tissue elasticity. The tissue gets deformed, arteriovenous anastomoses open; oxygen-poor blood starts to prevail in pulmonary vessels. Impaired gas exchange caused by interstitial edema, fluid buildup in the alveoli, increasingly more unventilated alveoli, and open arteriovenous anastomoses

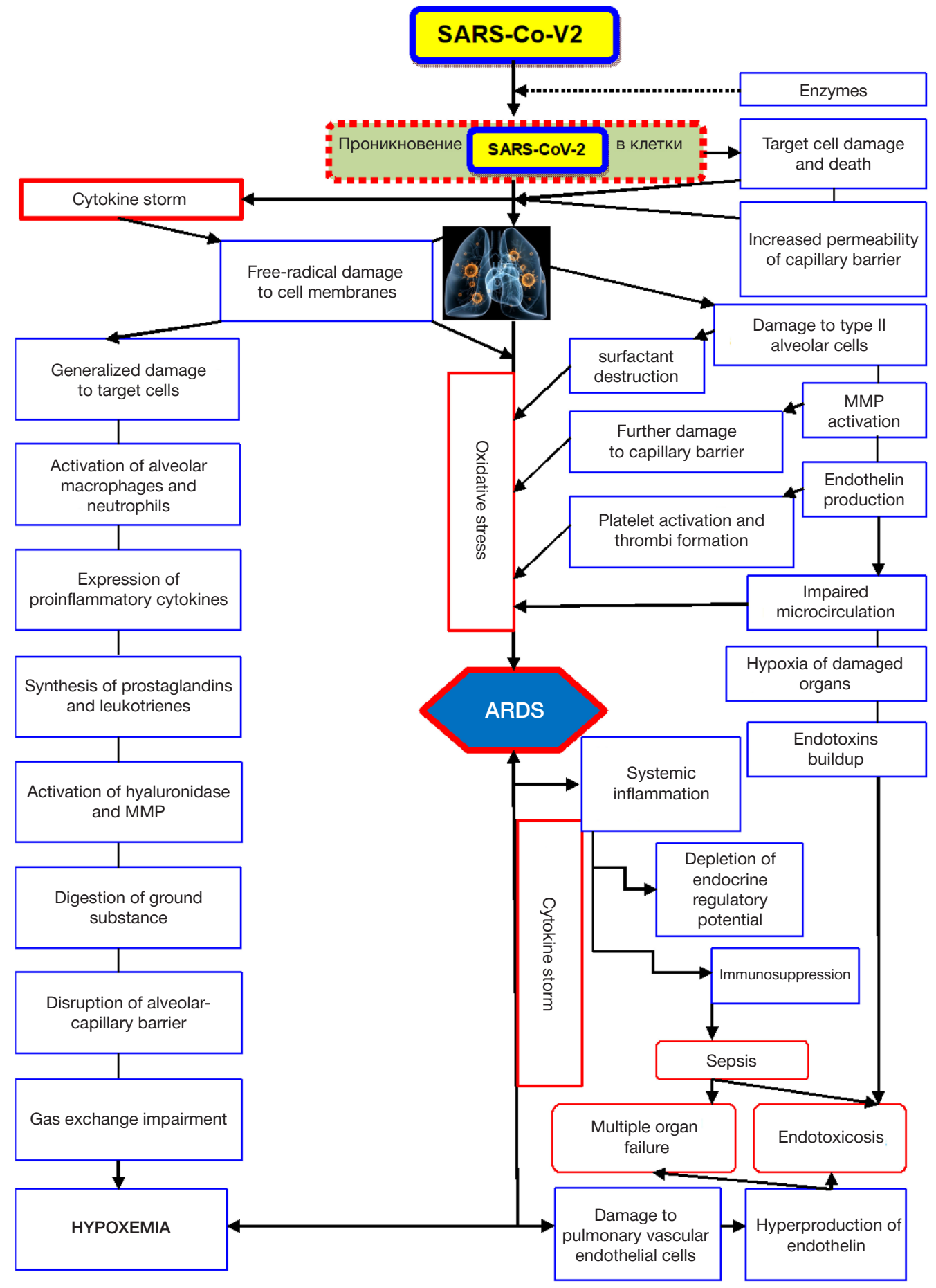

Fig. 2. The schematic representation of complications caused by the cascade of pathological responses to the novel coronavirus infection 
leads to hypoxemia. Under hypoxemic conditions, plasminogen activators (urokinase) are inhibited and fibrinolysis is suppressed.

Progressing endothelin secretion precipitates pulmonary vasoconstriction, platelet activation and intravascular thrombosis. This process is intensified by fibrinolysis inhibition and affects microcirculation. In turn, hypoxemia and poor microcirculation lead to hypoxia in the affected organs, accumulation of metabolic waste, endotoxins, and low to moderate molecular weight molecules, which further stimulates production of proinflammatory cytokines (tumor necrosis factor, IL-1, IL-6, IL-8) and promotes mononuclear cell migration.

Activated MMP exiting into the intercellular space from infected cells aggravate damage to the alveolar-capillary barrier and stimulate migration of neutrophils, macrophages, monocytes, and $T$ killers to the affected site. These events activate immune mechanisms involved in tissue damage and extracellular matrix destruction. Procollagen enters damaged alveoli and the interstitium, facilitating hyaline membrane formation in alveolar walls and causing interstitial compression. This further compromises the gas exchange function of the lungs. Neutrophil infiltration at the affected sites gives way to lymphocyte infiltration, which stimulates proliferation of fibroblasts, fibrin accumulation in the lungs and pulmonary tissue remodeling followed by the development of interstitial and intra-alveolar fibrosis.

Induced by respiratory failure, progressing hypoxemia and tissue hypoxia, coupled with direct viral damage to renal, pancreatic, cardiac and brain cells, drive progression of multiple organ failure, which signals a critical, life-threatening situation. Comorbidities only further aggravate a patient's condition. The ongoing cytokine storm maintains systemic inflammation, resulting in the inevitable depletion of endocrine regulatory potential, immunosuppression, opportunistic infections, sepsis, and endotoxic shock [36].

Being a trigger of multiple organ failure, hypoxemia necessitates prescription of coordinated zinc complexes capable of increasing hemoglobin affinity for oxygen. Coordinated zinc complexes hold promise for COVID-19 management as they can prevent death of infected cells.

Patients with COVID-19 complicated by pneumonia and the cytokine storm require intensive care that should include drugs inhibiting proinflammatory cytokines, such as recombinant analogs of endogenous cytokine receptor antagonists and therapeutic monoclonal antibodies. The Russian Ministry of Health has approved IL-6 receptor blockers for treating patients with COVID-19; among the approved drugs are tocilizumab, sarilumab, and olokizumab (monoclonal antibodies against IL-6), IL-1 $\beta$ inhibitors (canakinumab) and inhibitors of JAK kinase, which is the common signal pathway for many cytokines (ruxolitinib phosphate, baricitinib or tofacitinib). The therapeutic regimen can be enhanced with secukinumab (anti$\mathrm{IL}-17 \mathrm{~A})$ recommended by the protocol for the management of hospitalized COVID-19 patients developed by the Medical Research and Education Center of Moscow State University [37]

To reduce inflammation, combination therapy for viral pneumonias often includes synthetic inhibitory peptides (analogs of peripheral enkephalins) and T-cell inhibitors. MMP inhibitors can be effective against interstitial edema. So far, the only approved MMP inhibitor is doxycycline. Immune response can be downregulated with free-radical binding aminoquinolines and glucocorticoids implicated in suppressing initiators of tissue damage. For example, dexamethasone is now recommended by the UK Department of Health for treating ARDS in severely ill patients with COVID-19. This recommendation was based on the preliminary results of a large- scale British clinical study RECOVERY, which was conducted in 11,000 patients with COVID-19 and looked into the efficacy and safety of monotherapies with lopinavir+ritonavir, low doses of dexamethasone, hydroxychloroquine, azithromycin, tocilizumab, and hyperimmune donor plasma [38]. Glucocorticoids are also capable of suppressing hyperimmune response and enhance surfactant production. Pathological immune response induced by histamine release from the mast cells of the respiratory mucosa and pulmonary mesenchyme can be curbed by $\mathrm{H} 1$-histamine blockers.

Bradykinin receptor blockers might be effective in countering inflammation and blocking cascades initiated by bradykinin release from damaged macrophages, epithelial and endothelial cells, thereby reducing interstitial pulmonary edema. However, these drugs are not available in Russia and hence cannot be tested in a clinical trial.

Respiratory failure following ARDS requires emergency care involving oxygen therapy, mechanical ventilation and extracorporeal membrane oxygenation (ECMO). Perfluorochemicals (perftoran) are a promising therapeutic approach to treating hypoxemia, ARDS and multiorgan dysfunction syndrome. Perftoran possesses rheological, hemodynamic, diuretic, membrane-stabilizing, cardioprotective and sorption properties [39, 40].

Correction of endothelial dysfunction directly induced by SARS-CoV-2 or mediated by oxidative stress is a separate line of therapy. Endothelial dysfunction is a key element in the pathogenesis of many diseases [41]. So far, it has been shown to have a role in atherosclerosis, arterial hypertension, chronic heart failure, chronic obstructive pulmonary disease, urinary tract disorders, inflammatory bowel disorders, and other conditions $[42,43]$. The cascade of pathologic events triggered by COVID-19 complications can be viewed through the lens of endothelial dysfunction [44], whose severity largely determines the clinical outcome. In patients with COVID-19, endothelial dysfunction develops in 4 stages. Stage I is the onset of viral pneumonia, stage $\|$ is generalized pulmonary damage, stage III includes respiratory and cardiac failure, stage IV is characterized by progressing toxemia [41].

The primary cause underlying stage I is hypercytokinemia. Generalized pulmonary tissue damage (to types I and II alveolar cells, pulmonary macrophages) induced by the virus is followed by the aggressive activation of alveolar macrophages and neutrophils, expression of proinflammatory cytokines (IL-1, IL2, IL-6, IL-10, TNF) and activation of prostaglandin/leukotriene synthesis resulting in increased hyaluronidase activity. In turn, hyaluronidase digests the ground substance of the pulmonary interstitium and undermines the stability of the alveolar-capillary barrier. Proinflammatory cytokines and prostaglandins drive overexpression of selectins and adhesion molecules (ICAM-1, VCAM-1), which by interacting with leukocyte ligands foster their adhesion to the vascular endothelium and alveolar epithelium. This process is accompanied by a decline in endothelial $\mathrm{NO}$-synthase expression resulting in reduced nitrogen oxide production and reduced vasodilating, anticoagulatory and antiinflammatory endothelial function. Increased adhesion capacity of the endothelium and uncontrolled leukocyte adhesion have a significant role in the pathogenesis of local inflammatory response in ARDS and are implicated in renal damage, peripheral vasculitis and capillary purpura in later stages of the disease.

Generalized pulmonary damage is associated with direct damage to endothelial cells induced by SARS-CoV-2 circulating in the bloodstream. There are a few entry points for the virus on the surface of endothelial cells. This promotes endothelial 
dysfunction in pulmonary vessels, renal glomeruli, coronary and cerebral vessels. Damaged pulmonary vascular endothelial cells produce massive amounts of endothelin, provoking a local microvascular spasm and elevated arterial pressure [45]. Vascular fluid leaks into the interstitial space, causing interstitial edema, which impairs gas exchange between the capillaries and alveoli. This is followed by a dramatic loss of the gas exchange function, intensified hypoxemia, respiratory acidosis, and accumulation of carbon dioxide in the blood, which triggers hyperstimulation of respiratory and other brainstem centers controlling autonomic functions of the body. Respiratory failure progresses. In the kidneys, production of vasoconstricting $\mathrm{H}_{2}$ prostaglandins is more significant; it impairs glomerular blood flow and reduces excretion and reabsorption in distal nephron compartments.

During stage III (respiratory and circulatory failure), reduced blood flow, acidosis, hypoxemia and circulatory hypoxia exert their detrimental effects on the endothelium. Here, endothelial dysfunction is largely compensatory and aimed at improving microcirculation, lowering the increased vascular tone/ spasm of regional vessels. However, at this stage secretion of vasodilatory factors (nitrogen oxide, endothelium-derived relaxing factor, endothelium-derived hyperpolarizing factor) and procoagulants, especially plasminogen activator inhibitor and von von Willebrand factor. Fibrinolysis suppression and activation of a coagulation cascade allow intravascular microthrombi to persist and therefore are important pathogenetic factors for multiorgan dysfunction syndrome.

During stage IV, endothelial damage is linked to endotoxicosis ensuing from disruption of the intestinal capillary barrier and absorption of intestinal and microbial toxins, impaired detoxifying liver function (specifically, impaired ammonia detoxification during the urea cycle) and poor excretion of metabolic waste products by kidneys as a result of the acute renal failure onset. Exposed to endotoxins, endothelial cells are unable to maintain sufficient nutrient and energy supply, the negative charge on their surface, hemorheological and coagulation balance Fibronectin, a platelet activation factor, becomes overexpressed. Altogether, these factors condition intravascular thrombi, compromise microcirculation, suppress the healthy function of the affected organs. Activated platelets increasingly secrete the platelet-derived growth factor, a fibroblast mitogen; this leads to vigorous procollagen and collagen production, formation of hyaline membranes in the lungs and eventually to fibrotic transformation of lung tissue. Stages of endothelial dysfunction and their effects are shown in Fig. 3.

There is a broad spectrum of medications for treating endothelial dysfunction [42]. Apart from the drugs used to block cytokine activation of endothelial dysfunction, endothelin receptor antagonists, relaxin-2 receptor activators, synthetic prostaglandins and polysulfated glycosaminoglycans (sulodexide, fractionated and unfractionated heparin capable of restoring the negative charge on the endothelial surface) have already demonstrated their efficacy. Microcirculation can be improved by adenosine derivatives (dipyridamole), methylxanthines and nicotine acid. Therapy with angioprotective agents may benefit patients with COVID-19, since their mechanism of action is associated with dampening oxidative stress in the vascular wall and reducing vascular inflammation. In patients experiencing severe complications, including acute myocardial infarction, pulmonary embolism, ischemic stroke, retinal or renal thrombosis, fibrinolysis activators are recommended; however, contraindications to fibrinolytic therapy should be heeded.

Essential phospholipids are indicated for treating endothelial dysfunction [46]. They exert direct effects on cell membranes by improving membrane elasticity and fluidity, reducing the density of phospholipid structures, restoring membrane permeability, activating phospholipid-dependent enzymes and transport proteins. Phospholipids reduce damage to endothelial cells, help to restore normal metabolism and increase cell secretory

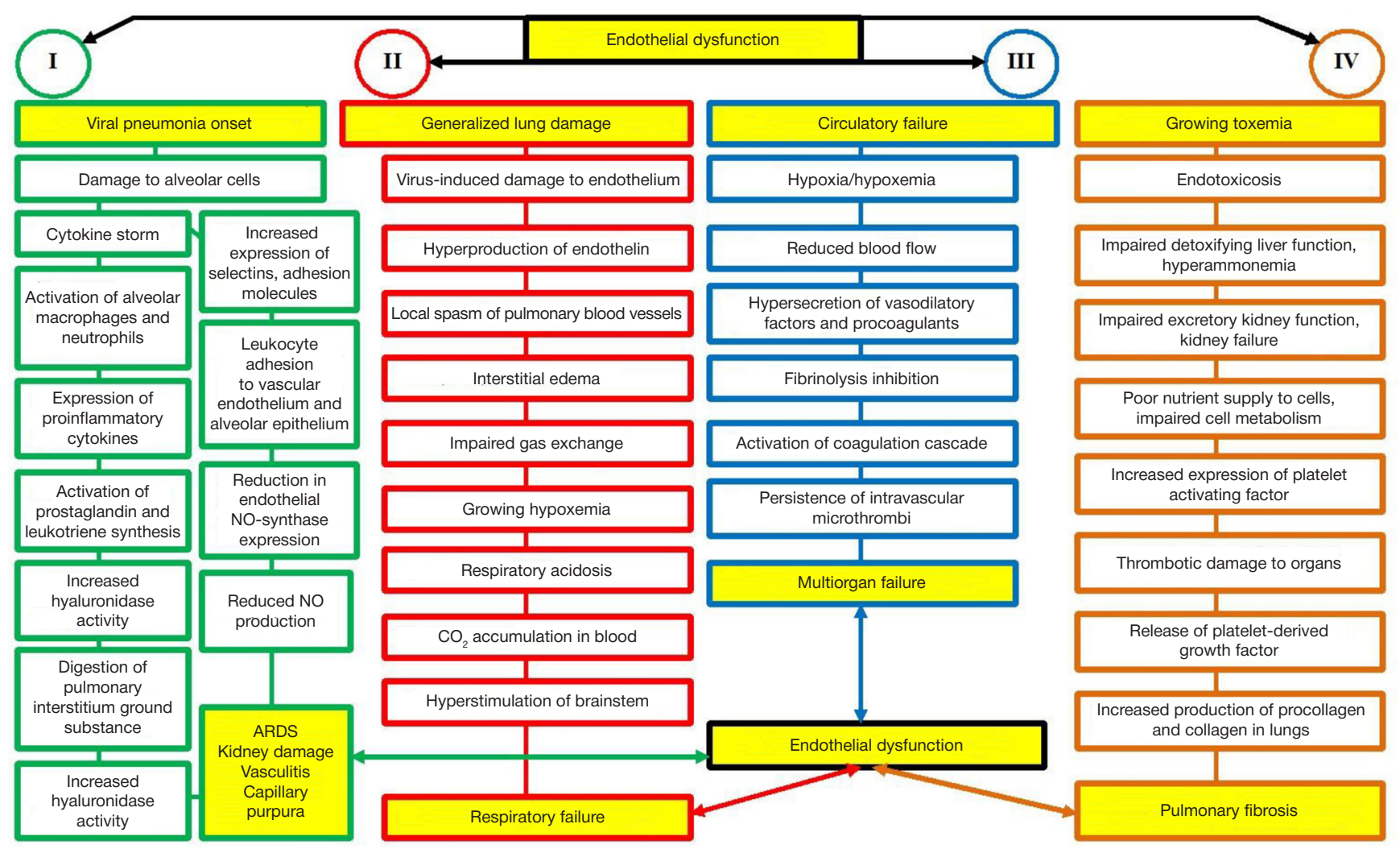

Fig. 3. Stages of endothelial dysfunction and their effects on the progression of pathology in patients with COVID-19 
(endocrine-regulatory) potential. Additionally, phospholipids are capable of inhibiting lipid peroxidation, lowering prostaglandin concentrations, downregulating Reticuloendothelial cells and curbing their collagen production. This allows considering phospholipids as candidates for treating COVID-19 consequences. On the whole, the convalescence period involves using a wide range of therapeutic interventions, including medication and physiotherapy. This stage largely determines the quality of a COVID-19 patient's recovery; therefore, rehabilitation regimens for patients with COVID-19 should be regularly updated and refined.

\section{CONCLUSION}

Regular updates on the mechanisms underlying pathological processes caused by SARS-CoV-2 allowed us to hypothesize the most probable pattern of the disease progression from the first moments of infection to ARDS, multiple organ failure and endotoxicosis. The article does not cover other types of interventions for treating viral pneumonias. Information presented here is not exhaustive and should be amended and augmented by experts in pathophysiology, pathomorphology, infectious diseases, immunology, pulmonology, and anesthesiology, as more clinical and laboratory data are collected. However, our analysis exposes the key principles in treating COVID-19. Those include a comprehensive strategy involving pharmacotherapy for the main pathogenesis components and accounting for the severity and stage of the disease and personalized treatment based on the thorough evaluation of a COVID-19 patient's health and assessment of chronic exogenous and endogenous risk factors for possible complications.

\section{References}

1. Ge H., Wang X., Yuan X., Xiao G., Wang Ch., Deng T., Yuan Q. Xiao $X$. The epidemiology and clinical information about COVID-19. Eur. J. Clin. Microbiol. Infect. Dis. 2020:1-9 Accessed March 20, 2020. https://www.ncbi.nlm.nih.gov/pmc/articles/PMC7154215/

2. Ahn D., Shin H., Kim M., Lee S., Kim H., Myoung J., Kim B. Kim S. Current status of epidemiology, diagnosis, therapeutics and vaccines for novel coronavirus disease 2019 (COVID-19). J. Microbiol. Biotechnol. 2020;30(3):313-324. Accessed March 20, 2020. https://doi.org/10.4014/jmb.2003.03011

3. Rothan H.A., Byrareddy S.N. The epidemiology and pathogenesis of coronavirus disease (COVID-19). J. Autoimmun. 2020;109. Accessed February 26, 2020. https://doi.org/10.1016/j. jaut.2020.102433

4. Gorenkov D.V., Khantimirova L.M., SHevtcov V.A., Rukavishnikov A.V., Merkulov V.A., Olefir Yu.V. An outbreak of a new infectious disease COVID-19: $\beta$-coronaviruses as a threat to global healthcare. Profilaktika, diagnostika, lechenie. 2020;20(1):6-20. (in Russian)

5. Zhmerenetsky K.V., Sazonova E.N., Voronina N.V., Tomilka G.S., Senkevich O.A., Gorokhovsky V.S., Dyachenko S.V., Koltsov I.P., Kutsiy M.B. COVID-19: scientific facts only. Dal'nevostochny medicinskij zhurnal. 2020;1:5-22.

6. Priputnevich T.V., Gordeev A.B., Lyubasovskaya L.A., SHabanova N.E. The new coronavirus SARS-CoV-2 and pregnancy: a literature review. Akusherstvo i ginekologiya. 2020;5:6-12.

7. Dubei M.J., Grosh R., Chatterjee S., Biswas P., Chatterjee S., Dubei S. COVID-19 and addiction. Diabetes Metab. Syndr. 2020;14(5):817823. https://www.ncbi.nlm.nih.gov/pmc/articles/PMC7282772/

8. Patanavanich R., Glantz S.A. Smoking is associated with COVID-19 progression: a meta-analysis. Nicotine Tob. Res. 2020. Accessed May 13, 2020. https://doi.org/10.1101/2020.04.13.20063669

9. Chick J. Alcohol and COVID-19. Alcohol and Alcoholism. 2020. Accessed May 13. https://doi.org/10.1093/alcalc/agaa039

10. Korostovceva L.S., Rotar' O.P., Konradi A.O. COVID-19: what are the risks of patients with hypertension? Arterial'naya gipertenziya. 2020;26(2):124-132. (in Russian)

11. Temporary guidelines. Prevention, diagnosis and treatment of new coronavirus infection (COVID-19). Version 7 from June 03, 2020 [archive]. The link is active on 15.06.2020. https://static-0. rosminzdrav.ru/system/attachments/attaches/000/050/584/ origi-nal/03062020_\%D0\%9CR_COVID-19_v7.pdf

12. Fantini J., Di Scala C., Chahinian H., Yahi N. Structural and molecular modeling studies reveal a new mechanism of action of chloroquine and hydroxychloroquine against SARS-CoV-2 infection. Int. J. Antimicrob. Agents. 2020;55(5). Accessed May. https://doi:10.1016/j.ijantimicag.2020.105960

13. Lauer S.A., Grantz K.N., Bi O., Jones F.K., Zheng Q., Meredith H.R., Azman A.S., Reich N.G., Lessler J. The incubation period of coronavirus disease 2019 (COVID-19) from publicly reported confirmed cases: estimation and application. Ann. Intern. Med.
2020:172(9):577-582. Accessed May 5, 2020. https://www. acpjournals.org/doi/10.7326/M20-0504

14. Yan R., Zhang Y., Xia L., Guo Y., Zhou Q. Structural basis for the recognition of SARS-CoV-2 by full-length human ACE2. Science. 2020:367(6485):1444-1448. Accessed March 27. https:// science.sciencemag.org/content/367/6485/1444

15. Hou Y., Peng C., Yu M., Li Y., Wang L.F., Shi Z. Angiotensinconverting enzyme 2 (ACE2) proteins of different bat species confer variable susceptibility to SARS-CoV entry. Arch.Virol. 2010;155(10):1563-1569. Accessed June 22, 2010. https:// www.ncbi.nlm.nih.gov/pmc/articles/PMC7086629/

16. Zou X., Chen K., Zou J., Han P., Hao J., Han Z. Single-cell RNAseq data analysis on the receptor ACE2 expression reveals the potential risk of different human organs vulnerable to 2019-nCoV infection. Front Med. 2020;14(2):185-192. Accessed March 12, 2020. https://www.ncbi.nlm.nih.gov/pmc/articles/PMC7088738/

17. Baklaushev V.P., Kulemzin S.V., Gorchakov A.A., Lesnyak V.N., Yusubalieva G.M., Sotnikova A.G. COVID-19. Aetiology, pathogenesis, diagnosis and treatment. Klinicheskaya praktika. 2020;11(1):7-20. (in Russian)

18. Miller J.K., Whittaker G.R. Physiological and molecular triggers for SARS-CoV membrane fusion and entry into host cells. Virology. 2018;517:3-8. Accessed December 21, 2017. https://www.ncbi. nlm.nih.gov/pmc/articles/PMC7112017/

19. Bradding P., Richardson M., Hinks T.S.C., Howarth P.H., Choy D.F., Arron J.R., Wenzel S.E., Siddiqui S. ACE2, TMPRSS2, and furin gene expression in the airways of people with asthmaimplications for COVID-19. J. Allergy Clin. Immunol. 2020;S00916749(20)20430-2. Accessed May 22, 2020. https://www.ncbi. nlm.nih.gov/pmc/articles/PMC7243787/

20. Kanekura T., Chen X., Kanzaki T. Basigin (CD147) is expressed on melanoma cells and induced tumor cell invasion by stimulating production of matrix metalloproteinases by fibroblasts. Int. J. Cancer. 2002;99(4)520-528. Accessed June 1, 2002. https://onlinelibrary.wiley.com/doi/full/10.1002/ ijc. 10390 ? sid=nlm\%3Apubmed

21. Vankadary N., Wilce J.A. Emerging WuHan (COVID-19) coronavirus: glycan shield and structure prediction of spike glycoprotein and its interaction with human CD26. Emerg. Microbes Infect. 2020;9(1):601-604. Accessed March 17, 2020. https://pubmed.ncbi.nlm.nih.gov/32178593/

22. Raj V.S., Mou H., Smits S.L., Dekkers D.H., Müller M.A., Dijkman R., Muth D., Demmers J.A., Zaki A., Foucher R.A., Thiel V., Drosten C., Rottier P.J., Osterhaus A.D., Bosch B.J., Haagmans B.L. Dipeptidyl peptidase 4 is a functional receptor receptor for the emerging human coronavirus-EMC. Nature. 2013;495(7440):251254. Accessed March 14, 2013. https://pubmed.ncbi.nlm.nih. gov/23486063/

23. Maggi E., Canonica C.W., Moretta L. COVID-19: unanswered 
questions on immune response and pathogenesis. J. Allergy Clin. Immunol. 2020;146(1):18-22. Published online May 8, 2020. https://www.ncbi.nlm.nih.gov/pmc/articles/PMC7205667/

24. Gurwitz D. Angiotensin receptor blockers as tentative SARSCoV-2 therapeutics. Drug Dev. Res. 2020;1-4. Accepted February 27, 2020. https://www.ncbi.nlm.nih.gov/pmc/articles/ PMC7228359/pdf/DDR-9999-na.pdf

25. Lei C., Fu W., Qian K., Li T., Zhang S., Ding M., Hu S. Potent neutralization of 2019 novel coronavirus by recombinant ACE2-lg. 2020. Posted February 3, 2020. https://www.biorxiv.org/content/ 10.1101/2020.02.01.929976v2.full.pdf

26. Samorodskaya I.V., Klyuchnikov I.V. Problems of diagnosis and treatment of COVID-19 on a clinical example. Vrach. 2020;31(4):19-25. (in Russian)

27. Speranskaya A.A. Radiological signs of a new coronavirus infection COVID-19. Luchevaya diagnostika i terapiya. 2020;1(11):18-25. (in Russian)

28. New coronavirus infection (COVID-19): etiology, epidemiology, clinic, diagnosis, treatment and prevention. M.:FMBA; 2020.

29. Belotserkovskaia Y.G., Romanovskikh A.G., Smirnov I.P. COVID-19: a respiratory infection caused by new coronavirus: new data on epidemiology, clinical course, and patients management. Consilium medicum. 2020;22(3):12-20. (in Russian)

30. Guo Y.R., Cao Q.D., Hong Z.S., Tan Y.Y., Chen S.D., Jin H.J., Tan K.S., Wang D.Y., Yan Y. The origin, transmission and clinical therapies on coronavirus disease 2019 (COVID-19) outbreak-an update on the status. Mil. Med. Res. 2020;7(1):11. Accessed March 13, 2020. https://pubmed.ncbi.nlm.nih.gov/32169119/

31. Polunina E.A., Belyakova I.S., YAkushev R.B. Oxidative stress in acute and chronic pathology of the bronchopulmonary system. Novaya nauka: strategii i vektory razvitiya. 2016;4-3(76):40-43. (in Russian)

32. Stavtseva S.N., Nikolaeva E.A., Sukhorukov V.S. Oxidative stress and mitochondrial dysfunction in the pathogenesis of Down's disease. Rossijskij vestnik perinatologii i pediatrii. 2014;3:39-42. (in Russian)

33. Ye Q., Wang B., Mao J. The pathogenesis and treatment of the "Cytokine Storm" in COVID-19. Journal of Infection. 2020. Accepted March 24, 2020. https://doi.org/10.1016/j. jinf.2020.03/037

34. Fisenko V.P., Chickova N.V. Current COVID-19 pandemic and pharmacological agents. Eksperimental'naya i klinicheskaya farmakologiya. 2020; 83 (4): 43-44. (in Russian)

35. Romanov B.K. Coronavirus disease COVID-2019. Bezopasnost i risk farmakoterapii. 2020;8(1):3-8. (in Russian)

36. Jamilloux Y., Henry T., Belot A., Viel S., Fauter M., Jammal T.El., Walzer T., François B., Sève P. Should we stimulate or suppress immune responses in COVID-19? Cytokine and anti-cytokine interventions. Autoimmun. Rev. 2020;19(7). https://www.ncbi. nlm.nih.gov/pmc/articles/PMC7196557/

37. Treatment Protocol COVID-19 medical center of Moscow state University [archive]. The link is active on 16.06.2020.http:// mc.msu.ru/protokol-mnoc.pdf

38. Recovery trial statement. Statement from the chief investigators of the randomised evaluation of COVID-19 therapy (recovery) trial on hydroxychloroquine. (5 June 2020). https://www.recoverytrial. net/files/hcq-recovery-statement-050620-final-002.pdf

39. Suhorukov V.P., Ragimov A.A., Pushkin S.YU., Maslennikov I.A., Bondar' O.G.Perfluorane is a perfluorocarbon blood substitute with a gas transport function.M.: Moskovskaya medicinskaya akademiya im. I.M. Sechenova; 2008. (in Russian)

40. Usenko L.V., Tsarev A.V. Perfluorane: current realities and prospects. Obshchaya reanimatologiya. 2007;3(1):5-7. (in Russian)

41. Mel'nikova Yu.S., Makarova T.P. Endothelian dysfunction as the key link jf chronic diseases pathogenesis. Kazanskij medicinskij zhurnal. 2015;96(4):659-665. (in Russian)

42. Dysfunction of the endothelium. Causes, mechanisms, pharmacological correction. Pod red. Petrishcheva N.N. SPb. Izdatel'stvo SPBGMU; 2003.

43. Baltaeva L.I., Pospelova J.S. Endothelian dysfunction is participation of the multiple sclerosis. Mezhdunarodnyj studencheskij vestnik. 2018; 4: 201-203. (in Russian)

44. Recommendations for the diagnosis and intensive therapy of disseminated intravascular coagulation syndrome in viral lung disease. Pod red. Vorobyova P.A., Elmykova V.A. M.: Moskovskoye gorodskoye obshchestvo terapevtov, 2020.

45. Dremina N.N., Shurigin M.G., Shurigina I.A. Endothelins under normal and pathological conditions. Mezhdunarodnyj zhurnal prikladnyh i fundamental'nyh issledovanij. 2016;10(2):210-214. (in Russian)

46. Rational pharmacotherapy in Hepatology: a guide for physicians. Pod red. Buerova A.O. M.: Littera; 2009.

\section{Литература}

1. Ge H., Wang X., Yuan X., Xiao G., Wang Ch., Deng T., Yuan Q., Xiao $X$. The epidemiology and clinical information about COVID-19. Eur. J. Clin. Microbiol. Infect. Dis. 2020:1-9 Accessed March 20, 2020. https://www.ncbi.nlm.nih.gov/pmc/articles/PMC7154215/

2. Ahn D., Shin H., Kim M., Lee S., Kim H., Myoung J., Kim B., Kim S. Current status of epidemiology, diagnosis, therapeutics and vaccines for novel coronavirus disease 2019 (COVID-19). J. Microbiol. Biotechnol. 2020;30(3):313-324. Accessed March 20, 2020. https://doi.org/10.4014/jmb.2003.03011

3. Rothan H.A., Byrareddy S.N. The epidemiology and pathogenesis of coronavirus disease (COVID-19). J. Autoimmun. 2020;109. Accessed February 26, 2020. https://doi.org/10.1016/j. jaut.2020.102433

4. Горенков Д.В., Хантимирова Л.М., Шевцов В.А., Рукавишников А.В., Меркулов В.А., Олефир Ю.В. Вспьшка нового инфекционного заболевания COVID-19: $\beta$-коронавирусы как угроза глобальному здравоохранению. Профилактика, диагностика, лечение. 2020;20(1):6-20.

5. Жмеренецкий К.В., Сазонова Е.Н., Воронина Н.В., Томилка Г.С., Сенькевич О.А., Гороховский В.С., Дьяченко С.В., Кольцов И.П., Куцый М.Б. COVID-19: только научные факты. Дальневосточный медицинский журнал. 2020;1:5-22.

6. Припутневич Т.В., Гордеев А.Б., Любасовская Л.А., Шабанова Н.Е. Новый коронавирус SARS-CoV-2 и беременность: обзор литературы. Акушерство и гинекология. 2020;5:6-12.

7. Dubei M.J., Grosh R., Chatterjee S., Biswas P., Chatterjee S., Dubei S. COVID-19 and addiction. Diabetes Metab. Syndr. 2020;14(5):817-

823. https://www.ncbi.nlm.nih.gov/pmc/articles/PMC7282772/

8. Patanavanich R., GlantzS.A. Smoking is associated with COVID-19 progression: a meta-analysis. Nicotine Tob. Res. 2020. Accessed May 13, 2020. https://doi.org/10.1101/2020.04.13.20063669

9. Chick J. Alcohol and COVID-19. Alcohol and Alcoholism. 2020. Accessed May 13. https://doi.org/10.1093/alcalc/agaa039

10. Коростовцева Л.С., Ротарь О.П., Конради А.O. COVID-19: каковы риски пациентов с артериальной гипертензией? Артериальная гипертензия. 2020;26(2):124-132.

11. Временные методические рекомендации. Профилактика, диагностика и лечение новой коронавирусной инфекции (COVID-19). Версия 7 от 03 июня 2020 г. [архив]. Ссылка активна на 15.06.2020. https://static-0.rosminzdrav. ru/system/attachments/attaches/000/050/584/original/03062020_\%D0\%9CR_COVID-19_v7.pdf

12. Fantini J., Di Scala C., Chahinian H., Yahi N. Structural and molecular modeling studies reveal a new mechanism of action of chloroquine and hydroxychloroquine against SARS-CoV-2 infection. Int. J. Antimicrob. Agents. 2020;55(5). Accessed May. https://doi:10.1016/j.ijantimicag.2020.105960

13. Lauer S.A., Grantz K.N., Bi O., Jones F.K., Zheng Q., Meredith H.R., Azman A.S., Reich N.G., Lessler J. The incubation period of coronavirus disease 2019 (COVID-19) from publicly reported confirmed cases: estimation and application. Ann. Intern. Med. 2020;172(9):577-582. Accessed May 5, 2020. https://www. acpjournals.org/doi/10.7326/M20-0504

14. Yan R., Zhang Y., Xia L., Guo Y., Zhou Q. Structural basis for the 
recognition of SARS-CoV-2 by full-length human ACE2. Science. 2020;367(6485):1444-1448. Accessed March 27. https:// science.sciencemag.org/content/367/6485/1444

15. Hou Y., Peng C., Yu M., Li Y., Wang L.F., Shi Z. Angiotensinconverting enzyme 2 (ACE2) proteins of different bat species confer variable susceptibility to SARS-CoV entry. Arch.Virol. 2010;155(10):1563-1569. Accessed June 22, 2010. https:// www.ncbi.nlm.nih.gov/pmc/articles/PMC7086629/

16. Zou X., Chen K., Zou J., Han P., Hao J., Han Z. Single-cell RNAseq data analysis on the receptor ACE2 expression reveals the potential risk of different human organs vulnerable to 2019-nCoV infection. Front Med. 2020;14(2):185-192. Accessed March 12 2020. https://www.ncbi.nlm.nih.gov/pmc/articles/PMC7088738/

17. Баклаушев В.Л., Кулемзин С.В., Горчаков А.А., Лесняк В.Н., Юсубалиева Г.М., Сотникова А.Г. COVID-19. Этиология, патогенез, диагностика, лечение. Клиническая практика. 2020;11(1):7-20.

18. Miller J.K., Whittaker G.R. Physiological and molecular triggers for SARS-CoV membrane fusion and entry into host cells. Virology. 2018;517:3-8. Accessed December 21, 2017. https://www.ncbi. nlm.nih.gov/pmc/articles/PMC7112017/

19. Bradding P., Richardson M., Hinks T.S.C., Howarth P.H., Choy D.F., Arron J.R., Wenzel S.E., Siddiqui S. ACE2, TMPRSS2, and furin gene expression in the airways of people with asthmaimplications for COVID-19. J. Allergy Clin. Immunol. 2020;S0091 6749(20)20430-2. Accessed May 22, 2020. https://www.ncbi. nlm.nih.gov/pmc/articles/PMC7243787/

20. Kanekura T., Chen X., Kanzaki T. Basigin (CD147) is expressed on melanoma cells and induced tumor cell invasion by stimulating production of matrix metalloproteinases by fibroblasts. Int. J. Cancer. 2002;99(4)520-528. Accessed June 1, 2002. https://onlinelibrary.wiley.com/doi/full/10.1002/ ijc. 10390 ? sid $=$ nIm\%3Apubmed

21. Vankadary N., Wilce J.A. Emerging WuHan (COVID-19) coronavirus: glycan shield and structure prediction of spike glycoprotein and its interaction with human CD26. Emerg. Microbes Infect. 2020;9(1):601-604. Accessed March 17, 2020. https://pubmed.ncbi.nlm.nih.gov/32178593/

22. Raj V.S., Mou H., Smits S.L., Dekkers D.H., Müller M.A., Dijkman R., Muth D., Demmers J.A., Zaki A., Foucher R.A., Thiel V., Drosten C. Rottier P.J., Osterhaus A.D., Bosch B.J., Haagmans B.L. Dipeptidyl peptidase 4 is a functional receptor receptor for the emerging human coronavirus-EMC. Nature. 2013;495(7440):251 254. Accessed March 14, 2013. https://pubmed.ncbi.nlm.nih. gov/23486063/

23. Maggi E., Canonica C.W., Moretta L. COVID-19: unanswered questions on immune response and pathogenesis. J. Allergy Clin. Immunol. 2020;146(1):18-22. Published online May 8, 2020 https://www.ncbi.nlm.nih.gov/pmc/articles/PMC7205667/

24. Gurwitz D. Angiotensin receptor blockers as tentative SARSCoV-2 therapeutics. Drug Dev. Res. 2020;1-4. Accepted February 27, 2020. https://www.ncbi.nlm.nih.gov/pmc/articles/ PMC7228359/pdf/DDR-9999-na.pdf

25. Lei C., Fu W., Qian K., Li T., Zhang S., Ding M., Hu S. Potent neutralization of 2019 novel coronavirus by recombinant ACE2-Ig 2020. Posted February 3, 2020. https://www.biorxiv.org/content/ 10.1101/2020.02.01.929976v2.full.pdf

26. Самородская И.В., Ключников И.В. Проблемы диагностики и лечения COVID-19 на клиническом примере. Врач. 2020;31(4):19-25.

27. Сперанская А.А. Лучевые проявления новой коронавирусной инфекции COVID-19. Лучевая диагностика и терапия. 2020;1(11):18-25.

28. Новая коронавирусная инфекция (COVID-19): этиология, эпидемиология, клиника, диагностика, лечение и профилактика. М.:ФМБА; 2020.

29. Белоцерковская Ю.Г., Романовских А.Г., Смирнов И.П. COVID-19: респираторная инфекция, вызванная новым коронавирусом: новые данные об эпидемиологии, клиническом течении, ведении пациентов. Consilium medicum. 2020;22(3):12-20.

30. Guo Y.R., Cao Q.D., Hong Z.S., Tan Y.Y., Chen S.D., Jin H.J., Tan K.S., Wang D.Y., Yan Y. The origin, transmission and clinical therapies on coronavirus disease 2019 (COVID-19) outbreak-an update on the status. Mil. Med. Res. 2020;7(1):11. Accessed March 13, 2020. https://pubmed.ncbi.nlm.nih.gov/32169119/

31. Полунина Е.А., Белякова И.С., Якушев Р.Б. Оксидативный стресс при острой и хронической патологии бронхолегочной системы. Новая наука: стратегии и векторы развития. 2016;43(76):40-43.

32. Ставцева С.Н., Николаева Е.А., Сухоруков В.С. Окислительный стресс и митохондриальная дисфункция в патогенезе болезни Дауна. Российский вестник перинатологии и педиатрии. 2014;3:39-42.

33. Ye Q., Wang B., Mao J. The pathogenesis and treatment of the "Cytokine Storm" in COVID-19. Journal of Infection. 2020. Accepted March 24, 2020. https://doi.org/10.1016/j. jinf.2020.03/037

34. Фисенко В.П., Чичкарева Н.В. Современная пандемия COVID-19 и лекарственные средства. Экспериментальная и клиническая фармакология. 2020;83(4):43-44.

35. Романов Б.К. Коронавирусная инфекция COVID-2019. Безопасность и риск фармакотерапии. 2020;8(1):3-8.

36. Jamilloux Y., Henry T., Belot A., Viel S., Fauter M., Jammal T.El., Walzer T., François B., Sève P. Should we stimulate or suppress immune responses in COVID-19? Cytokine and anti-cytokine interventions. Autoimmun. Rev. 2020;19(7). https://www.ncbi. nlm.nih.gov/pmc/articles/PMC7196557/

37. Протокол лечения COVID-19 медицинского центра МГУ [архив]. Ссылка активна на 16.06.2020. http://mc.msu.ru/ protokol-mnoc.pdf

38. Recovery trial statement. Statement from the chief investigators of the randomised evaluation of COVID-19 therapy (recovery) trial on hydroxychloroquine. (5 June 2020). https://www.recoverytrial. net/files/hcq-recovery-statement-050620-final-002.pdf

39. Сухоруков В.П., Рагимов А.А., Пушкин С.Ю., Масленников И.А., Бондарь О.Г. Перфторан - перфторуглеродный кровезаменитель с газотранспортной функцией. М.: Московская медицинская академия им. И.М. Сеченова; 2008.

40. Усенко Л.В., Царев А.В. Перфторан - современные реалии и перспективы. Общая реаниматология. 2007;3(1):5-7.

41. Мельникова Ю.С., Макарова Т.П. Эндотелиальная диссфункция как центральное звено патогенеза хронических болезней. Казанский медицинский журнал. 2015;96(4):659-665.

42. Дисфункция эндотелия. Причины, механизмы, фармакологическая коррекция. Под ред. Петрищева Н.Н. СПб.: Издательство СПБГМУ; 2003.

43. Балтаева Л.И., Поспелова Ю.С. Участие эндотелиальной дисфункции в развитии рассеянного склероза. Международный студенческий вестник. 2018;4:201-203.

44. Рекомендации по диагностике и интенсивной терапии синдрома диссеминированного внутрисосудистого свертывания крови при вирусном поражении легких. Под ред. Воробьева П.А., Елыкомова В.А. М.: Московское городское общество терапевтов; 2020

45. Дремина Н.Н., Шурыгин М.Г., Шурыгина И.А. Эндотелины в норме и патологии. Международный журнал прикладных и фундаментальных исследований. 2016;10(2):210-214.

46. Рациональная фармакотерапия в гепатологии: руководство для врачей. Под ред. Буерова А.О. М.: Литтера; 2009. 